form of cabinet summons, the communications of the cabinet with the sovereign, the extent to which it works through committees of its body, and avails itself of the evidence of outsiders, may give a practical character to historical inquiry and help us to understand the institution as it existed in the eighteenth century.

WIILLAY R. Axsor.

\title{
England and Holland at the beginning of the Nineteenth Century
}

TwENTY years ago the period of Dutch history subsequent to the fall of the republic was not regarded in Holland as a subject worthy of serious historical research. It is true that two or three of the leading Dutch historians had published something on the 'French period'-as the time from 1795 to 1813 is conventionally known in Holland-but even Fruin, the Dutch Ranke, did not occupy himself seriously with the history of those years, and used to conclude his academical lectures and his historical studies with the last years of the declining republic. We are now more fortunate. Not only are the teaching of Dutch history at the universities and historical research continued far into the nineteenth century, but there are also at our disposal extensive publications of records covering the whole of the French period. I refer to the excellent book of Dr. Colenbrander, director of the board for historical publications at the Hague, who, as readers of this Review are aware, ${ }^{1}$ has already published eleven big volumes of records relating to this time, ${ }^{2}$ collected from Dutch and foreign archives and intended to be continued down to 1840. This work contains several thousand letters and documents, elucidated by notes and connected by explanatory paragraphs, and there are excellent indexes. It is acknowledged to be a publication of high rank.

It is this work which ensbles me to call attention to the marked change in British policy with regard to Holland about 1800, a change which has had its effects in Anglo-Dutch diplomatic and commercial relations down to the present day. From the times of William III, and particularly from 1689 , in which year the close alliance between England and Holland was concluded, till the end of the ancient Dutch republic, the nature of the relations between the two 'sea powers' on the opposite shores of the North Ses had been threefold : political, directed in the first place against France and her conquering spirit ; commercial,

\footnotetext{
1 Sec ante, nxi 598-600 (1906), zriii 5851. (1913).

- Gedenkstukten der algemeene Geschiedenio wan Nederland (Den Harg, Nijhoff, $1905-13)$.
} 
opening a period of more friendly competition instead of the 'Anglo-Dutch rivalry' 3 of the seventeenth century; personal, by the marriages of Princes William III and William IV with English princesses. About 1780 these relations had received a severe blow: opposing political and commercial interests had, during the American revolt, caused a war which faintly recalled the heroic sea-fights of the seventeenth century; but soon the internal and external crisis in Holland had passed away, and in 1788 Holland concluded a new close alliance with England and Prussia, which powers undertook to guarante the maintenance of the Dutch aristocratic republican constitution under the hereditary stadtholdership of the house of Orange.

But the old republic succumbed rapidly before the efforts to strengthen her failing frame had any success; her military and financial impotence and the ineffective support of the AngloAustrian forces, commanded by generals of questionable ability, rendered her a 'most miserable deficiant' ally, who could not be helped by the almost dictatorial power of Lord Auckland, ${ }^{5}$ the British ambassador at the Hague, and left her an easy prey to the French revolutionary army of Pichegru, who entered her territory in 1794 and conquered her in January 1795. So began the period of French domination in the new Batavian republic, modelled upon the French example, which slavishly followed the destinies of France for nearly twenty years.

During the first years of the Batavian republic the Orange party, however feeble and discouraged, still possessed a majority in the people as a whole, and it was more or less attached to the old political system, to the old commercial friendship, and to the old personal relations with England. But there was a strong and active minority, supported by France and bitterly hostile to England, which had ruined Dutch commerce by blockade and embargo, had destroyed the new Dutch fleet at Camperdown (1797), and was seeking to restore the unfortunate stadtholder William $\nabla$ with all the drawbacks of aristocratic government, which they considered to be the origin of all the Dutch troubles. So strong was this minority, so feeble the sympathy of the majority with the old government and the former system of foreign politics, that at the time of the Anglo-Russian invasion of 1799 there was no chance of a general Dutch rising against the French or even merely in favour of the Prince of Orange. English and Dutch agents had boasted of the possibility, even the probability, of such a revolt in the Batavian republic, and of the inclination of the reigning Dutch government itself to surrender the country

3 Edmundson, Anglo-Dutch Rivalry (Oتford, 1911).

- Colenbrander, i. 289.

- Ibid. p. 293. 
to the Anglo-Russian invaders and to the hereditary Prince of Orange, who accompanied them ; but the fear of French revenge, the lack of real confidence in the old government and its leaders, checked all ideas of rising for independence and for a restoration of the house of Orange.

This experience had its influence on the attitude of the English government, which had felt some compunction at the slight assistance rendered before the fall of the ancient republic, but now resolved to make the best of the situation. Pitt and Grenville decided to throw over the house of Orange and to try to find some way at least of restoring the former commercial relations, the lack of which was seriously felt in English commercial and industrial circles, for Holland had been for the last century the door for English exports into Germany, Belgium, and Austria. Perhaps, so the English government thought, it would be possible to separate Holland, humiliated as she was, from France and to support her by means of political neutrality. Perhaps the Dutch people, suffering seriously by the continual blockade, might be brought back to the old maxim, long ago upheld by John de Witt in these words, 'even if the Devil reigned over these Isles [of England], we must have peace with them'. Perhaps bitter experience of the last years would bring the Dutch to the conviction that political and commercial friendship with England was preferable to an alliance with France.

The negotiations at Amiens, originally begun by Pitt, led to the peace, concluded by the Addington administration, and Anglo-Dutch commercial and political relations revived in consequence. A great many English manufactures entered Holland; Dutch products, German and Belgian cargoes in Dutch ships; went in large quantities over to England; the Dutch colonies, which had been seized by England during the war, were restored, Ceylon alone excepted; Schimmelpenninck, the foremost Dutch diplomatist, who had done important service in promoting the peace of Amiens, went to London as an ambassador. But general peace reigned only for a year, and then the great Napoleonic war commenced. There was a faint hope in Holland that the new French raler might be persuaded to consent to Dutch neutrality by the offer of a large sum of money, for after all her reverses Holland was still comparatively wealthy. But this hope vanished, and Holland, where forty millions of English debt had been placed from about 1760 , had again to go to war with England, led by the indomitable conqueror. She submitted to her fate, but reluctantly, for she always endeavoured to carry on her foreign trade, even with England; and resorted to smuggling, interloping, and sailing with Dutch cargo under a foreign flag.

- See the Grenville pepers of this time. 
And England, glad to be provided with foreign goods, shut her eyes to this illegal but profitable kind of commerce. Napoleon, in pursuance of his project of annihilating English commerce by universal exclusion, forced his policy on Holland; England answered by the renewal of blockade and embargo, by stopping the payment of English interest, and so Dutch commerce and Dutch revenue were ruined anew, while political relations came to an end altogether. Holland did what she could, even under the reign of King Louis Napoleon, the satrap and unwilling servant of the great emperor. She brought smuggling to a high degree of perfection, and tried to maintain some diplomatic relations of an ambiguous character by the aid of financial and semi-Orangist agents. But England, under Pitt and Fox, Portland and Perceral, had for the moment lost all hopes of Holland; neither whigs nor tories saw any chance of liberating Holland from her French chains, bound faster and faster, and at last simply uniting the country to the French empire.

After 1799 England had thrown over the house of Orange, hoping to make some arrangement with the Batavian republic, which appeared to have forgotten the house of Orange, now ruling its German estates, but soon deprived also of those, and trying to find a new life, a military life in Prussian, Austrian, or English service. After Amiens there had been some hope of an independent neutral Holland. After 1803 there was only a hostile Holland, a country in fact forming a part of France, which succeeded in incorporating the valusble river-delta within her own borders. The Dutch colonies, now little more than French dependencies, were conquered by arms one after another and converted into English colonies; last, in 1811, the richest of them all, Java. Holland herself, expelled from the sea, deprived of her colonies over the seas, began to cast her eyes on continental trade and continental industry, thinking to live on them in the future as she had lived for centuries on sea-trade and. fishery, thus hopelessly trying to change her own nature and that of her inhabitants.

But 1812 came and the Russian campaign with its disasters, followed next year by the rising of half Europe against France. What would Holland do? The Prince of Orange tried to seize the occasion, and came to England from Germany in order. to seo what could be done for Holland, where many people, after Moscow, cherished some hope of recovering independence under the Orange flag, and where Orangist agents began to prepare something like a revolt. But the summer of 1813 was full of uncertainty and of equivocal diplomacy, not favourable to projects of that kind. After the battle of Leipzig courage rose higher, and the allies coming near to the Dutch eastern frontiers, 
the courageous Van Hogendorp and his friends hoisted the Orange banner at the Hague. The weak French forces left in Holland occupied some fortified towns on the coast and on the rivers; these places soon became islands in a tempestuons sea of revolt. English aid in arms and ammunition, an English army in Zeeland and Brabant, a Prussian army entering from the east, proceded by Russian Cossacks, soon came to the rescue. It is to the everlasting honour of Van Hogendorp and his friends that they gave the signal to the hesitating allies and organized the revolt. On 30 November the Prince of Orange came over from England, where Castlereagh had discussed with him several political, personal, and commercial points regarding the fate of Holland, to place himself at the head of affairs.

It was on this foundation, laid in London by Orange and Castlereagh, that a new Holland arose, strengthened by the enlargement of her territory with that of conquered Belgium, conquered by the allies, by the consolidation of her new monarchical government under the house of Orange, receiving back from England most of her lost colonies as a simple gift.

This new Holland, the kingdom of the Netherlands, promised to be a firm friend to England, a sentinel to her and to Europe on the northern frontier of France, her commercial and industrial friend; bound to her by the remembrance of English aid in 1813, to her reigning house by the proposed marriage of the hereditary prince William to the English Princess Royal Charlotte of Wales. It was the old idea of the eighteenth century in a new form, which again haunted the English cabinet. But the Dutch had other views. The sentinel did not fulfil expectations : he cast not unfriendly eyes on his partner across the hostile border and for financial reasons somehow neglected the fortifications he had to look after. The projected commercial and industrial friendship soon became a kind of rivalry, Dutch commerce and Belgian industry coming to the world's market with views and projects of their own. And the hoped-for personal union of the two reigning houses came to nothing, Leopold of Coburg becoming the husband of the English heiress. Then came the Belgian revolution of 1830 , which severed the union with the southern provinces, actually with the aid of disillusioned England and with the eager support of France. Ancient Holland revived in the kingdom which still flourishes; the English illusions of 1813 had vanished into smoke.

The ideals of 1802 and 1813 of close intimacy between England and Holland were never fulfilled. Holland chose to be independent, wholly independent, of England, to cultivate moderate politics of her own, and to retire from diplomatic difficultieg, aroiding alike friction and engagements with any 
power greater than herself, and at last working silently for the world's peace. The establishment of the court at the Hague, soon to possess a worthy seat of the peaceful ideals of the world, was a kind of triumph for her own peaceful intentions. In the second half of the ninetenth century Holland developed her commerce and industry on the same principles as England - the ancient principles of her own glorious past, now promoted by England-without any shadow of jealousy and rivalry from either side; and she has been enabled to reach a high standard of prosperity not unlike, even surpassing, that of the best times of the ancient republic. Without personal ties in the way which had been looked forward to by the English and Dutch leaders of 1813-a marriage scheme between the Dutch prince Alexander of Orange, son of William II, and the Princess Victoria twenty years afterwards soon fell through-the reigning houses have, like the two nations themselves, maintained a friendship devoid of political consequences and strong enough to outlive temporary storms. P. J. BLов. 